\title{
Bacterial Leaf Spot of Leafy Crucifers in Oklahoma Caused by Pseudomonas syringae pv. maculicola
}

\author{
Youfu Zhao, John P. Damicone, Department of Entomology and Plant Pathology; David H. Demezas, Department \\ of Microbiology and Molecular Genetics; Vidhya Rangaswamy and Carol L. Bender, Department of Entomology \\ and Plant Pathology, Oklahoma State University, Stillwater 74078
}

\begin{abstract}
Zhao, Y. F., Damicone, J. P., Demezas, D. H., Rangaswamy, V., and Bender, C. L. 2000. Bacterial leaf spot of leafy crucifers in Oklahoma caused by Pseudomonas syringae pv. maculicola. Plant Dis. 84:1015-1020.

During 1995 and 1996, bacterial leaf spots severely damaged fields of kale, spinach mustard, and turnip in Oklahoma. Symptoms were small, brown, necrotic spots with irregular edges surrounded by chlorotic halos. Lesion margins were often water-soaked on the abaxial surface. The spots enlarged and coalesced, causing extensive leaf yellowing and necrosis. Nineteen strains of a fluorescent Pseudomonas spp. were isolated from symptomatic plants. LOPAT tests and carbon source oxidation using Biolog GN MicroPlates were used to classify the strains as $P$. syringae. Cluster analysis of carbon source oxidation profiles for the local strains and selected reference strains of $P$. syringae pv. maculicola and pv. tomato produced one group with $79.5 \%$ similarity. In spray inoculations, all local strains caused chlorotic or water-soaked lesions on collards, kale, cauliflower, and tomato. A few local strains caused necrotic lesions on mustard. Most local strains caused one of the three lesion types on turnip and spinach mustard. Reference strains of $P$. syringae pv. maculicola caused similar symptoms. All but three of the local strains produced coronatine in vitro. The local strains were thus classified as $P$. syringae pv. maculicola, the cause of bacterial leaf spot of crucifers. Two distinct groups of $P$. syringae pv. maculicola were identified by repetitive sequence-based polymerase chain reaction (rep-PCR) with both REP and BOXA1R primers. Three subgroups within each group were further identified using the BOXA1R primer. Except for two strains of $P$. syringae pv. tomato which were pathogenic on crucifers, the pathovars maculicola and tomato had different genetic fingerprints. The pathogen was recovered from seven of ten fields sampled during 1994 to 1996. In five of the fields with $P$. syringae pv. maculicola, pathovars of Xanthomonas campestris were also isolated from lesions forming a bacterial disease complex. This is the first report of bacterial leaf spot caused by $P$. syringae pv. maculicola on leafy crucifers in Oklahoma.
\end{abstract}

The leafy crucifers collard (Brassica oleracea var. viridis L.), kale (B. oleracea var. sabellica L.), mustard (B. juncea L. var. crispifolia Bailey), spinach mustard (B. rapa $\mathrm{L}$. var. perviridis Bailey), and turnip (B. rapa var. utilis (D.C.) Metzg.) are important minor crops in Oklahoma that are grown for processing. About 600 ha are grown each year during both spring and fall cropping seasons (2). The crops are direct seeded and harvested in bulk with non-selective cutters up to three times per cropping season. Because of the nonselective harvesting procedure, leaf blemishing from disease can reduce product grade and value. Product from severely diseased fields may be discounted or even rejected by processors, resulting in total economic loss.

Corresponding author: John P. Damicone

E-mail:.jpd3898@okstate.edu

Accepted for publication 2 June 2000.

Publication no. D-2000-0713-02R

(C) 2000 The American Phytopathological Society
During 1994 to 1996, fields of turnip, spinach mustard, mustard, and kale in the Arkansas River Valley of eastern Oklahoma were severely damaged by bacterial leaf spots. Symptoms were circular to irregular shaped necrotic lesions with yellow halos. Lesion size ranged from $2 \mathrm{~mm}$ to over $1 \mathrm{~cm}$ in size. Chlorotic haloes surrounding isolated spots were narrow ( 1 to 2 $\mathrm{mm})$. However, chlorosis was general on areas of leaves where lesions were numerous. The margins of lesions were often water-soaked on the abaxial leaf surface. On severely diseased leaves, lesions coalesced to cause extensive leaf necrosis and death. Up to $70 \%$ of leaves were affected. Where disease incidence was lower, affected leaves were usually of a similar age. Fluorescent Pseudomonas spp. and Xanthomonas campestris were isolated from diseased leaves. Two pathovars of X. campestris, pv. campestris, the cause of black rot, and pv. armoraciae, the cause of Xanthomonas leaf spot, were identified as important components of the leaf spot diseases $(31,32)$.

Bacterial leaf spot, also known as pepper spot, is a previously reported bacterial disease of crucifers caused by $P$. syringae pv. maculicola (6). The disease was first reported by McCulloch on cauliflower $(B$. oleracea var. botrytis L.) in 1911 (22). Since then, it has been reported in at least 32 countries where cauliflower and other Brassica spp. are grown (6). Bacterial leaf spot is prevalent in cool coastal areas (27) where it causes severe losses on cauliflower and broccoli (B. oleracea L. var. italica Plenck. [30]). In Argentina, a severe epidemic was recently reported on Brussels sprouts $(B$. oleracea $L$. var. gemmifera Zenk. [1]). P. syringae pv. maculicola is also pathogenic on tomato (Lycopersicon esculentum Mill. [6,28,30]), and is closely related to $P$. syringae pv. tomato, the cause of bacterial speck of tomato $(9,11,28,30)$. A new, unnamed pathovar of $P$. syringae was recently reported to cause leaf spot and blight of broccoli raab (B. ruvo Bailey [16]). The pathovar produced symptoms on crucifers that were similar to those caused by $P$. syringae pv. maculicola, but it was nonpathogenic on tomato and caused disease on some grass species (16).

Typical symptoms caused by $P$. syringae pv. maculicola are small, brown, necrotic spots with irregular edges surrounded by chlorotic halos (27). However, the pathogen causes a variety of symptoms that include chlorotic, water-soaked, and necrotic lesions $(7,22,30)$. P. syringae pv. maculicola is known to produce coronatine, a chlorosis-inducing, non-host specific phytotoxin that functions as an important virulence factor $(5,30)$. Coronatine production has been used as a diagnostic tool to identify $P$. syringae pv. maculicola and other coronatine-producing pathovars of $P$. syringae (3-5).

Repetitive sequence-based polymerase chain reaction fingerprinting, referred to as rep-PCR, has been successfully used to identify and classify bacteria $(20,21)$. Three families of repetitive sequences have been successfully used, including the 35 to $40 \mathrm{bp}$ repetitive extragenic palindromic (REP) sequence, the 124 to $127 \mathrm{bp}$ enterobacterial repetitive intergenic consensus (ERIC) sequence, and the $154 \mathrm{bp}$ BOX element. Genomic fingerprints generated with REP-, ERIC-, and BOX-PCR have been used for the rapid identification of pathovars and bacterial strains $(19,20,21)$ and for studies on genetic diversity (12).

In a recent national assessment of the importance of diseases of leafy green vegetables and their management, bacte- 
rial leaf spots were not recognized (2). The objective of this study was to identify and characterize the strains of fluorescent Pseudomonas spp. isolated from leafy crucifers in Oklahoma. A preliminary report of this work has been published (32).

\section{MATERIALS AND METHODS}

Bacterial strains. Bacterial strains were isolated from leaves of kale, spinach mustard, and turnip with symptoms of leaf spot that were collected from 10 fields in eastern Oklahoma from 1994 to 1996 (Table 1). Leaf pieces with lesions were excised from diseased leaves, surface sterilized in $0.25 \%$ aqueous sodium hypochlorite for 30 $\mathrm{sec}$, and rinsed in sterile tap water. The leaf pieces were macerated in a few drops of sterile tap water and the extract was streaked onto nutrient agar (NA). Plates were incubated at $28^{\circ} \mathrm{C}$ and examined at 3 to 5 days for bacterial growth. Colonies resembling Pseudomonas spp. were purified on NA and tested for fluorescence on King's medium B (KB [15]) and gram reaction using standard methods (26). Fluorescent, gram-negative strains were retained and subjected to LOPAT tests, which include production of arginine dihydrolase, levan, and oxidase; ability to rot potato; and induction of the hypersensitive reaction in tobacco leaves (17). Known strains of $P$. syringae pv. maculicola and pv. tomato were obtained from various sources and used as reference strains (Table 1). Bacterial strains were stored in $15 \%$ glycerol at $-70^{\circ} \mathrm{C}$ and were routinely cultured on $\mathrm{KB}$, mannitol-glutamate me- dium (MG), or MG containing $0.01 \%$ yeast extract (14) at $28^{\circ} \mathrm{C}$.

Carbon source oxidation and utilization. Strains were typed for oxidation of the 95 carbon sources available on the GN MicroPlates (Biolog Inc., Hayward, CA). Bacteria were grown on trypticase soy agar (TSA; Bacto Tryptic Soy Broth, 15 g/liter agar; Difco Laboratories, Detroit, MI) for $24 \mathrm{~h}$ at $28^{\circ} \mathrm{C}$. Cells were transferred from the plates to $30 \mathrm{ml}$ test tubes containing 20 $\mathrm{ml}$ of sterile saline $(0.85 \% \mathrm{NaCl})$. The optical density (OD) of the suspension was determined at $590 \mathrm{~nm}$ and adjusted as recommended by the manufacturer (13). Microplates were inoculated with $150 \mu$ of bacterial suspension per well and incubated at $28^{\circ} \mathrm{C}$. The absorbance $\left(A_{590}\right)$ of the wells was recorded at $24 \mathrm{~h}$ using a plate reader (Molecular Devices Corp., Sunnyvale, CA) controlled by SOFTmax (version 1.02). The data were converted to ASCII format with SMAX123. MicroLog 2 (version 3.5, Biolog Inc., Hayward, CA), and the GN database (version 3.5) was used for strain identification. Similarity coefficients were determined using NTSYS-PC (24). Cluster analysis was performed using the unweighted pair-group method, and dendrograms were generated using the SAHN subroutine of NTSYS-PC. The repeatability of the assay was confirmed by running a set of 18 arbitrarily selected strains twice. The assay then was performed on the 19 local strains and on four reference strains each of $P$. syringae pv. maculicola and pv. tomato.

Utilization of sorbitol and homoserine, useful for grouping strains of $P$. syringae pv. maculicola and pv. tomato (9), was determined for each strain. Ayer's minimal salt medium (11) was amended with $0.1 \%$ sorbitol or homoserine, inoculated, and incubated at $28^{\circ} \mathrm{C}$. Growth at 14 days was indicative of substrate utilization.

Pathogenicity tests. Pathogenicity and host range was determined by spray inoculation of cauliflower (cv. Snow Crown), collard (cv. Vates), kale (cv. Dwarf Blue Curled Scotch), mustard (cv. Southern Giant Curled), spinach mustard (cv. Tendergreen), turnip (cv. Hybrid Alltop), and tomato (cv. Summer Flavor 3000). Strains were grown on NA or $\mathrm{KB}$ at $28^{\circ} \mathrm{C}$ for $48 \mathrm{~h}$ and cells were suspended in sterile tap water to a concentration of approximately $1 \times 10^{7} \mathrm{CFU} / \mathrm{ml}$ as determined by dilution plating and OD readings $\left(A_{600}=0.05\right)$. Plants were produced from seed in 12.7$\mathrm{cm}$-diameter pots containing soilless media (Metro-Mix 200, Scotts-Sierra Horticultural Products Co., Marysville, $\mathrm{OH}$ ). Plants were maintained in a greenhouse at 20 to $25^{\circ} \mathrm{C}$, thinned to one per pot at the cotyledon stage, and fertilized every 2 weeks with soluble 20-20-20 (N-P-K) fertilizer. Plants were incubated in polyethylene humidity chambers within the greenhouse at $100 \%$ relative humidity for 24 to $48 \mathrm{~h}$ before and after inoculation. Bacterial suspensions were applied with an artist's airbrush at $172 \mathrm{kPa}$ until leaves were uniformly wet. After removal from the chambers, plants were maintained in the greenhouse until symptoms were assessed 7 to 14 days after inoculation. Symptoms were classified by lesion type as previously described (30). Chlorotic lesions were brown,

Table 1. Bacterial strains used in this study ${ }^{x}$

\begin{tabular}{|c|c|c|c|c|}
\hline Strain & Field-year & Host & Location & Source (reference) \\
\hline \multicolumn{5}{|c|}{ Pseudomonas syringae pv. maculicola } \\
\hline $\mathrm{F} 1$ & 2-1995 & Spinach mustard ${ }^{\mathrm{y}}$ & Oklahoma & This study \\
\hline NF2, NF3, NF3a & $3-1995$ & Turnip & Oklahoma & This study \\
\hline F6, F18, F19 & 4-1995 & Turnip & Oklahoma & This study \\
\hline NF4, NF5, F7, NF12 & $5-1995$ & Spinach mustard ${ }^{\mathrm{z}}$ & Oklahoma & This study \\
\hline F16, F17 & $6-1995$ & Spinach mustard ${ }^{\mathrm{z}}$ & Oklahoma & This study \\
\hline F9, F10a, F15 & $7-1995$ & Kale & Oklahoma & This study \\
\hline F20, F21, F22 & 9-1996 & Spinach mustard ${ }^{y}$ & Oklahoma & This study \\
\hline 16391,16392 & & Cauliflower & Florida & R. Stall \\
\hline 17223,17225 & & Brassica sp. & Florida & R. Stall \\
\hline 1820 & 1965 & Radish & California & D. Cuppels (9) \\
\hline $84-59,84-67$ & 1984 & Cauliflower & California & D. Cuppels $(9,30)$ \\
\hline $88-10$ & 1988 & Cauliflower & California & D. Cuppels $(9,30)$ \\
\hline 4981 & 1970 & Cauliflower & Zimbabwe & D. Cuppels $(9,30)$ \\
\hline $90-32$ & 1990 & Cauliflower & California & D. Cuppels (9) \\
\hline 4326 & 1965 & Radish & United States & C. Bender (30) \\
\hline \multicolumn{5}{|c|}{ Pseudomonas syringae pv. tomato } \\
\hline 6198 & & Tomato & Oklahoma & R. Stall \\
\hline $9861,9865,9867$ & & Tomato & Florida & R. Stall \\
\hline $\mathrm{OH} 314$ & & Nettle & Ohio & D. Cuppels (9) \\
\hline DC84-1 & 1984 & Tomato & Ontario & D. Cuppels (9) \\
\hline DC3000 & & Tomato & United Kingdom & D. Cuppels \\
\hline 487 & 1979 & Tomato & Greece & D. Cuppels (9) \\
\hline 3357 & 1972 & Tomato & New Zealand & D. Cuppels (9) \\
\hline
\end{tabular}

${ }^{\mathrm{x}}$ Reference strains were from C. Bender, co-author; D. Cuppels, Agriculture and Agri-Food Canada, London, Ontario N5V 4T3; and R. Stall, Department of Plant Pathology, University of Florida, Gainesville 32611. Local strains were isolated from leaf spots on leaves from seven fields in eastern Oklahoma and were identified based on results of this study.

y Cultivar Savannah, which is used by the processor as a mustard green.

${ }^{\mathrm{z}}$ Cultivar Tendergreen, which is used by the processor as a turnip green. 
water-soaked, and surrounded by yellow zones of chlorosis. Water-soaked lesions were the same as chlorotic lesions, but lacked a chlorotic border. Necrotic lesions were tan to brown, dry, and also lacked a chlorotic border. Three replicate plants of each crop were inoculated with each strain and the entire set of inoculations was repeated. Water was used as a control for each set of inoculations.

Coronatine production. A rapid extraction method was used to determine in vitro production of coronatine as described previously (23). Briefly, bacteria were cultured in $10 \mathrm{ml}$ Hoitink-Sinden medium optimized for coronatine production and incubated at $18^{\circ} \mathrm{C}$ for 5 days at $280 \mathrm{rpm}$. Coronafacoyl compounds were extracted from culture supernatants with ethyl acetate, evaporated, and resuspended in $0.5 \mathrm{ml}$ of $10 \%$ acetonitrile in $0.05 \%$ trifluoracetic acid. Extracts were analyzed by high-pressure liquid chromatography (HPLC) as described previously (23). Three extractions per strain were performed. $P$. syringae pv. glycinea strains PG4180.N9 and PG4180.G109 were included as positive and negative controls, respectively.

Rep-PCR. Rep-PCR was carried out as described by Versalovic et al. (29). The REP primers REP1R-1[5'-IIIICGICGICAT CIGGC] and REP2-1[5'-ICGICTTATCIG GCCTAC] were synthesized by Genosys (The Woodlands, TX) (20,29). The BOX primer BOXA1R [5'-CTACGGCAAGG CGACGCTGACG] was synthesized by the Oklahoma State University Recombinant DNA/Protein Resource Facility. Bacteria initially were grown on NA at $28^{\circ} \mathrm{C}$ for 24 $\mathrm{h}$, and then transferred to $5 \mathrm{ml}$ of LuriaBertani broth (25) and incubated at $28^{\circ} \mathrm{C}$, $280 \mathrm{rpm}$, for $18 \mathrm{~h}$. Aliquots $(1 \mathrm{ml})$ were centrifuged, and pellets were washed in 0.5 $\mathrm{ml}$ of $0.5 \mathrm{M} \mathrm{NaCl}$ and then resuspended in $50 \mu \mathrm{l}$ sterile distilled water to a final density of $10^{10} \mathrm{CFU} / \mathrm{ml}$. Repetitive DNA elements were amplified using REP and BOX primers in $25 \mu$ l reaction volumes. Each reaction consisted of $1 \times$ Gitschier buffer (16.6 $\mathrm{m} M\left[\mathrm{NH}_{4}\right]_{2} \mathrm{SO}_{4} ; 67 \mathrm{~m} M \mathrm{HCl}, \mathrm{pH}$ 8.8; $6.7 \mathrm{~m} M \mathrm{MgCl}_{2}$; $6.7 \mathrm{~m} M$ EDTA; 30 $\mathrm{m} M$ B-mercaptoethanol), $4 \mu \mathrm{g}$ bovine serum albumin, $10 \%$ dimethyl sulfoxide (v/v) (Fluka Chemical Corp., Ronkonkoma, NY), 50 pmoles of each primer, 1.25 $\mathrm{m} M$ of each dNTP (Boehringer Mannheim, Indianapolis, IN), 2 units of Taq polymerase (Promega, Madison, WI), and $1 \mu$ of the bacterial suspension. Each reaction set included a negative control containing water only. Reaction mixtures were overlaid with $25 \mu$ l of sterile mineral oil. The PCR was carried out in a DNA thermal cycler 480 (Perkin-Elmer Cetus, Norwalk, $\mathrm{CN}$ ) as follows: 1 cycle at $95^{\circ} \mathrm{C}$ for $6 \mathrm{~min}$, 30 cycles at $94^{\circ} \mathrm{C}$ for $1 \mathrm{~min}, 40^{\circ} \mathrm{C}$ (REP) or $50^{\circ} \mathrm{C}(\mathrm{BOX})$ for $1 \mathrm{~min}$, and $65^{\circ} \mathrm{C}$ for 8 min, followed by $65^{\circ} \mathrm{C}$ for $16 \mathrm{~min}$. An $8 \mu \mathrm{l}$ aliquot of the PCR product was analyzed by gel electrophoresis on $1.5 \%$ agarose gel at $70 \mathrm{~V}$ for $5 \mathrm{~h}$ in $1 \times$ TBE buffer $(\mathrm{pH} \mathrm{8.3)}$ ). Gels were stained with ethidium bromide and differences in DNA fingerprint patterns were assessed visually. Each strain was assayed twice.

\section{RESULTS}

Bacterial strains. A total of 29 strains of fluorescent pseudomonads was recovered from the fields of leafy crucifers sampled. Colonies were white, circular, entire, and convex. All strains were gram negative and had strong bluish green fluorescence on both $\mathrm{KB}$ and MG plates. In LOPAT tests, 19 strains were positive for levan production and the hypersensitive response on tobacco; but negative for oxidase, arginine dihydrolase, and potato rot. The 19 strains belonged to LOPAT group Ia and were presumably $P$. syringae. These 19 strains of $P$. syringae were recovered from seven of the ten sampled fields and were isolated from kale, spinach mustard, and turnip (Table 1). The remaining 10 strains belonged to LOPAT groups II, IVa, and Va, and likely were $P$. viridiflava (3 strains), $P$. fluorescens (3 strains), and P. putida (4 strains), respectively.

Carbon source oxidation and utilization. The Biolog GN database classified the 19 putative strains of $P$. syringae (described above) and the four reference strains of each $P$. syringae pv. maculicola and pv. tomato that were assayed as $P$. syringae. The database classified 13 of the 19 local strains and three of the eight reference strains as $P$. syringae pv. pisi, with similarity coefficients ranging from 52 to $87 \%$. Other strains were classified as $P$. syringae pv. tabaci, pv. tomato, pv. hibisci, and pv. porri with similarity ranging from 60 to $89 \%$. Only reference strain 9867 was correctly classified as $P$. syringae pv. tomato. Cluster analysis of the carbon source oxidation profiles for the 19 local strains of $P$. syringae, including the four reference strains of each pathovar produced one group at $79.5 \%$ similarity (Fig. 1). Subgroups at $>90 \%$ similarity contained local and reference strains of both pathovars.

All 19 local strains of $P$. syringae, three of the reference strains of $P$. syringae pv. maculicola, and all reference strains of $P$. syringae pv. tomato utilized sorbitol, but not homoserine (Table 2). However, five reference strains of $P$. syringae pv. maculicola utilized neither carbon source.

Pathogenicity. The 19 local strains of $P$. syringae caused chlorotic or water-soaked lesions on cauliflower, collards, and kale

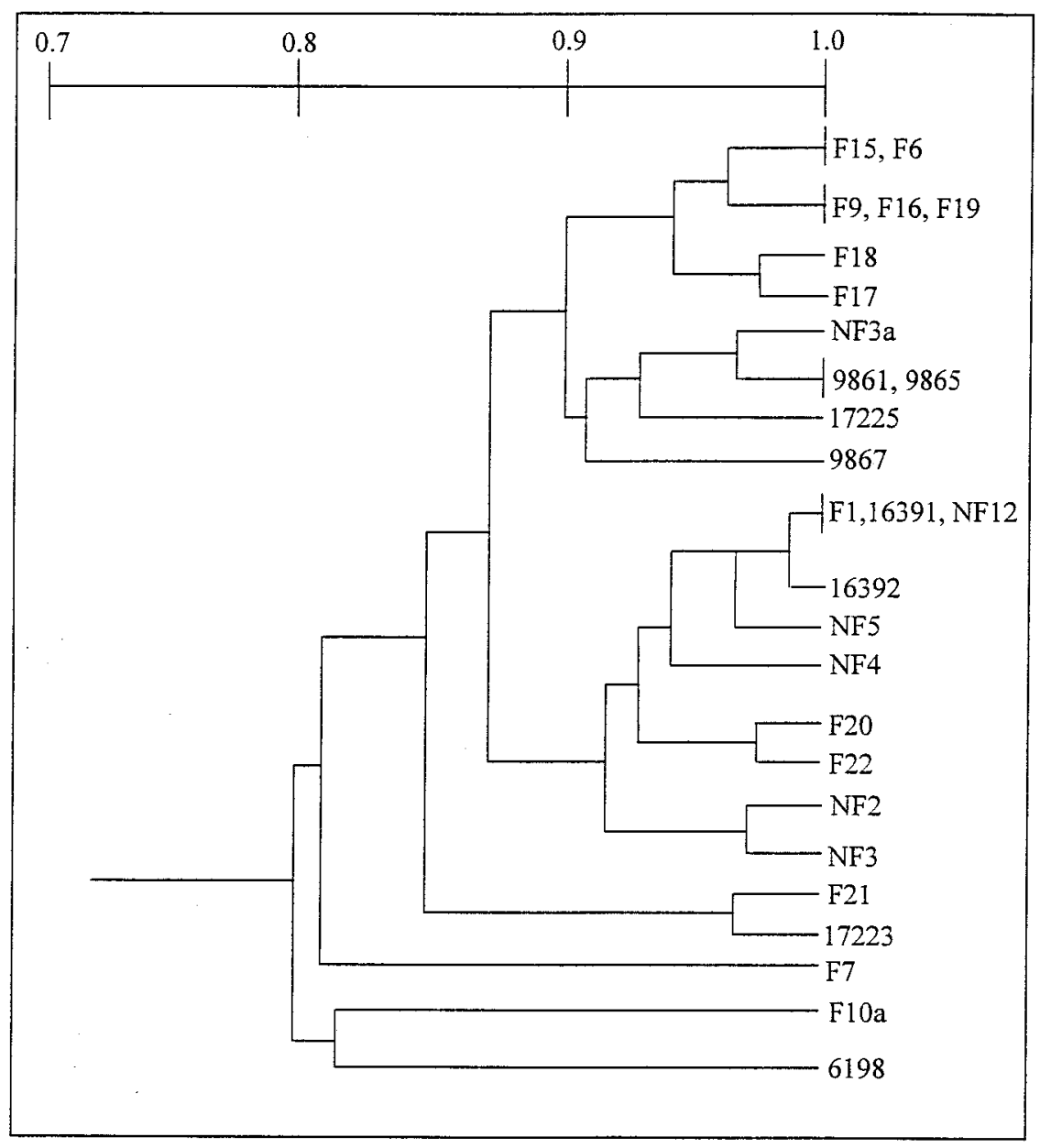

Fig. 1. Dendrogram showing the similarity among strains of Pseudomonas syringae for carbon source oxidation as determined with GN MicroPlates (Biolog, Inc., Hayward, CA). 
(Table 2). Pathogenicity of the local strains of $P$. syringae was more variable on mustard, spinach mustard, and turnip (Table 2). Except for strains F18, F20, F21, and F22, which caused necrotic lesions, most strains were nonpathogenic on mustard. Thirteen of the strains were pathogenic on turnip and caused necrotic, water-soaked, or chlorotic lesions. All but four strains were pathogenic on turnip, causing either chlorotic or water-soaked lesions. Chlorotic and water-soaked lesions were interveinal, circular to irregular in shape, brown, and water-soaked on the abaxial surface. On tomato, all 19 strains caused either chlorotic or water-soaked lesions on leaves. Spots were small (1 to $2 \mathrm{~mm}$ diameter) and brown. $P$. syringae was isolated from lesions on representative plants and was confirmed to be the same bacteria after characterization.

Reference strains of $P$. syringae pv. maculicola caused similar symptoms when inoculated on these crops (Table 2). However, reference strains induced a more uniform symptom expression across crops. Except for strains from Florida (16391,
16392, 17223, and 17225) which caused chlorotic and water-soaked lesions, reference strains caused chlorotic lesions on all crops tested. All reference strains of $P$. syringae pv. tomato except DC3000 and OH314 caused chlorotic or water-soaked lesions on tomato, but were nonpathogenic on crucifers (Table 2). Strains DC3000 and OH314 caused chlorotic lesions on crucifers and tomato and were similar in pathogenicity to reference strains of $P$. syringae pv. maculicola.

Based on pathogenicity, the 19 local strains of $P$. syringae were designated as pv. maculicola. The 10 local strains of Pseudomonas spp. which were classified as $P$. viridiflava, $P$. fluorescens, or $P$. putida, were nonpathogenic on all crops inoculated (data not shown). Control plants inoculated with water remained symptomless.

Coronatine production. Among the 19 local strains of $P$. syringae pv. maculicola, 16 produced coronatine in vitro (Table 2 ). Most reference strains also produced coronatine in vitro, except for strains 16391 and 16392 of $P$. syringae pv. maculicola and strain 6198 of $P$. syringae pv. tomato.
Coronatine was detected for the positive control (PG4180.N9), but not for the negative control (PG4180.G109).

Symptom expression for several strains varied on different host plants despite coronatine production in vitro (Table 2). The coronatine-producing strains F20, 17223, 17225 of $P$. syringae pv. maculicola caused water-soaked lesions without chlorosis on one or more crucifer crops. Strains NF3, NF3a, NF4, 16391 and 16392 which did not produce coronatine, caused chlorotic lesions on one or more crops.

Rep-PCR. Genomic fingerprints were generated for all strains of $P$. syringae (Table 1). More than 20 DNA fragments ranging in size from 0.2 to $4.0-\mathrm{kb}$ were amplified with the REP or BOXA1R primers. Based on the genomic fingerprints using both the REP (data not shown) and BOXA1R primers, two distinct groups were identified for strains of $P$. syringae pv. maculicola, which were arbitrarily designated as group A and B (Fig. 2). Strains DC3000 and OH314 of P. syringae pv. tomato showed identical fingerprints to strains of $P$. syringae pv. maculicola in

Table 2. Pathogenicity, host range, carbon source utilization, coronatine production, and genetic fingerprint groups using repetitive sequence-based polymerase chain reaction fingerprinting (rep-PCR) for strains of Pseudomonas syringae pv. maculicola from crucifers and P. syringae pv. tomato

\begin{tabular}{|c|c|c|c|c|c|c|c|c|c|c|}
\hline \multirow[b]{2}{*}{ Strain } & \multicolumn{7}{|c|}{ Pathogenicity $^{v}$} & \multirow[b]{2}{*}{$\mathbf{S} / \mathbf{H}^{\mathbf{w}}$} & \multirow[b]{2}{*}{$\operatorname{COR}^{\mathrm{x}}$} & \multirow[b]{2}{*}{$\begin{array}{r}\text { rep-PCF } \\
\text { group }^{y}\end{array}$} \\
\hline & Collards & Kale & Mustard & $\begin{array}{l}\text { Spinach } \\
\text { mustard }\end{array}$ & Turnip & Cauliflower & Tomato & & & \\
\hline \multicolumn{11}{|l|}{ pv. maculicola } \\
\hline F1 & $\mathrm{CL}$ & CL & _- & $\mathrm{CL}$ & $\mathrm{CL}$ & $\mathrm{CL}$ & $\mathrm{CL}$ & $+/-$ & + & $\mathrm{A} 1$ \\
\hline F7 & $\mathrm{CL}$ & CL & - & - & $\mathrm{CL}$ & CL & CL & $+/-$ & + & A1 \\
\hline F6 & $\mathrm{CL}$ & CL & - & NL & - & CL & CL & $+/-$ & + & $\mathrm{A} 2$ \\
\hline F9, F10a & $\mathrm{CL}$ & CL & - & CL & $\mathrm{CL}$ & CL & CL & $+/-$ & + & $\mathrm{A} 2$ \\
\hline F16 & $\mathrm{CL}$ & $\mathrm{CL}$ & - & - & - & CL & CL & $+/-$ & + & $\mathrm{A} 2$ \\
\hline F17 & $\mathrm{CL}$ & CL & - & - & - & CL & $\mathrm{CL}$ & $+/-$ & + & $\mathrm{A} 2$ \\
\hline F18 & $\mathrm{CL}$ & $\mathrm{CL}$ & NL & CL & $\mathrm{CL}$ & CL & CL & $+/-$ & + & $\mathrm{A} 2$ \\
\hline F19 & $\mathrm{CL}$ & CL & - & - & $\mathrm{CL}$ & CL & CL & $+/-$ & + & $\mathrm{A} 2$ \\
\hline F15 & $\mathrm{CL}$ & CL & - & - & - & CL & CL & $+/-$ & + & A3 \\
\hline NF2, NF5 & $\mathrm{CL}$ & CL & - & NL & $\mathrm{CL}$ & CL & CL & $+1-$ & + & B1 \\
\hline $\mathrm{NF} 12$ & WS & WS & - & NL & WS & WS & WS & $+/-$ & + & B1 \\
\hline NF3 & WS & CL & - & NL & $\mathrm{CL}$ & WS & CL & $+/-$ & - & B1 \\
\hline NF3a & $\mathrm{CL}$ & $\mathrm{CL}$ & - & NL & $\mathrm{CL}$ & CL & WS & $+/-$ & - & B1 \\
\hline NF4 & $\mathrm{CL}$ & WS & - & WS & WS & CL & WS & $+/-$ & - & B1 \\
\hline F20 & $\mathrm{CL}$ & CL & NL & WS & CL & CL & CL & $+1-$ & + & B3 \\
\hline $\mathrm{F} 21$ & $\mathrm{CL}$ & $\mathrm{CL}$ & NL & - & $\mathrm{CL}$ & CL & CL & $+/-$ & + & B3 \\
\hline F22 & WS & WS & NL & WS & WS & WS & WS & $+/-$ & + & B3 \\
\hline $84-67$ & $\mathrm{CL}$ & $\mathrm{CL}$ & $\ldots$ & $\mathrm{CL}$ & $\mathrm{CL}$ & CL & $\mathrm{CL}$ & $-1-z$ & + & $\mathrm{A} 1$ \\
\hline $84-59,88-10,90-32$ & $\mathrm{CL}$ & CL & $\cdots$ & CL & CL & CL & CL & $-1-z$ & + & A2 \\
\hline 4981 & $\ldots$ & $\ldots$ & $\ldots$ & $\ldots$ & $\ldots$ & $\ldots$ & $\ldots$ & $+/-z$ & $t^{\mathrm{z}}$ & A3 \\
\hline 16391 & WS & WS & NL & $\mathrm{CL}$ & WS & WS & WS & $+/-$ & - & B1 \\
\hline 16392 & WS & CL & WS & CL & WS & WS & CL & $+1-$ & - & $\mathrm{B} 1$ \\
\hline 17223 & WS & WS & $\mathrm{CL}$ & CL & $\mathrm{CL}$ & WS & CL & $-1-$ & + & $\mathrm{B} 2$ \\
\hline 17225 & CL & WS & CL & CL & CL & CL & CL & $-1-$ & + & $\mathrm{B} 2$ \\
\hline 4326 & $\mathrm{CL}$ & CL & $\ldots$ & CL & $\mathrm{CL}$ & CL & CL & $-1-$ & + & B2 \\
\hline 1820 & $\ldots$ & $\ldots$ & $\ldots$ & $\ldots$ & $\ldots$ & $\ldots$ & $\ldots$ & $-1-z^{z}-1-1$ & $t^{\mathrm{Z}}$ & B2 \\
\hline \multicolumn{11}{|l|}{ pv. tomato } \\
\hline DC3000, OH314 & $\mathrm{CL}$ & $\mathrm{CL}$ & $\ldots$ & CL & $\mathrm{CL}$ & $\mathrm{CL}$ & CL & $-1-z$ & + & $\mathrm{A} 2$ \\
\hline 6198 & - & - & - & - & - & - & WS & $+/-$ & - & $\mathrm{C}$ \\
\hline 9861,9865 & - & - & - & - & - & - & CL & $+/-$ & + & $\mathrm{C}$ \\
\hline 9867 & - & - & - & - & - & - & WS & $+1-$ & + & $\mathrm{C}$ \\
\hline DC84-1, 487, 3357 & - & - & - & - & - & - & CL & $+/-z$ & $t^{\mathrm{z}}$ & $\mathrm{C}$ \\
\hline
\end{tabular}

${ }^{v}$ Symptom type 7 to 14 days after spray inoculation and incubation in humidity chambers: $(\mathrm{CL})=$ chlorotic lesion, $(\mathrm{NL})=$ necrotic lesion, $(\mathrm{WS})=$ watersoaked lesion, $(-)=$ no symptoms, $(\ldots)=$ not determined. Three replicate plants of each crop were inoculated per strain and the experiment was repeated.

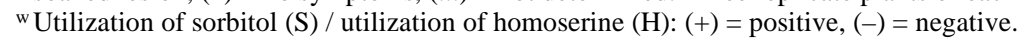

${ }^{x}$ Coronatine production: $(+)=$ positive, $(-)=$ negative.

y Groupings by banding pattern of rep-PCR products using the BOXA1R primer (see Fig. 2).

${ }^{z}$ Data from Cuppels and Ainsworth (9). 
group A (Fig. 2). All other strains of $P$. syringae pv. tomato formed group $\mathrm{C}$, which was quite different from either group A or B (Fig. 2). The groups defined by the REP and BOXA1R primers were consistent for both pathovars and identical groupings were obtained with both primer sets. The difference between groups A and $\mathrm{B}$ was greater than that between groups $\mathrm{A}$ and C. Group A contained 10 local and 5 reference strains of $P$. syringae pv. maculicola, and strains DC3000 and OH314 of $P$. syringae pv. tomato (Table 2). Group B contained 9 local and 6 reference strains of $P$. syringae pv. maculicola (Table 2). Within each group, the fingerprints were similar; however, the BOXA1R primer clearly divided groups A and B into three subgroups that were arbitrarily designated as A1 to A3 and B1 to B3 (Fig. 2 and Table 2). Within group A, polymorphisms were identified in the 0.35 to $1-\mathrm{kb}$ region (Fig. 2). Within group $\mathrm{B}$, the polymorphisms between subgroups were located in the 1 to $2-\mathrm{kb}$ region (Fig. 2).

\section{DISCUSSION}

P. syringae pv. maculicola was identified as a cause of bacterial leaf spot of leafy crucifers in Oklahoma. The pathogen was isolated from diseased leaves of turnip, spinach mustard, and kale in 1995 and 1996. It was recovered from seven of the ten fields sampled during 1994 to 1996. $X$. campestris pvs. armoraciae and/or campestris were recovered from diseased leaves in the other three fields $(31,32)$. One or both pathovars of $X$. campestris and $P$. syringae pv. maculicola were isolated from lesions in five fields, forming a disease complex. The symptoms caused by $P$. syringae pv. maculicola are similar to those incited by $X$. campestris pathovars. It is not known whether the bacteria caused mixed infections such as those reported for these genera on tomato (10). This is the first report of bacterial leaf spot of crucifers caused by $P$. syringae pv. maculicola in Oklahoma.

In spray inoculations, local strains of $P$. syringae pv. maculicola varied in their pathogenicity on different leafy crucifer crops. All strains were pathogenic on collards and kale. However, most local strains were nonpathogenic on mustard, and a few were nonpathogenic on turnip and spinach mustard. Using rub inoculation, Wiebe and Campbell (30) reported variability in the pathogenicity of three strains of $P$. syringae pv. maculicola on several crucifer hosts. Weak symptom development was reported for all three strains on mustard, whereas symptoms were severe on turnip for one strain, but weak for the others. In that study, temperature also influenced pathogenicity and virulence. Therefore, environmental conditions may be important for infection and disease development. In this study, spray inoculations were done in the greenhouse where temperature ranged from 20 to $25^{\circ} \mathrm{C}$. However, temperatures were within the range reported to favor moderate to severe disease development for the pathogen (30). Other potentially important environmental factors known to favor severe development of bacterial diseases in the field include wind-driven rain and aerosols, and abrasion from wind-blown sand. Preliminary inoculations with leaf infiltration provided more uniform results than spraying, but this method was rejected because symptoms were not typical of those observed in the field. Differences in cultivar reaction to the disease may also be important in pathogenicity and symptom expression.

In spray inoculations, some strains of $P$. syringae pv. maculicola produced variable symptoms on the different crucifer hosts. Local strains produced the three different lesion types described elsewhere for this and other pathovars of $P$. syringae $(16,30)$. Differences in symptom expression could not be explained by the ability of a strain to produce coronatine in vitro. The three local strains that did not produce coronatine in vitro produced chlorotic lesions in planta in one or more crops. Several coronatineproducing strains produced water-soaked lesions without chlorosis on one or more crops. These results suggest that coronatine production in planta may vary with the host plant and may be differentially regulated in some strains.

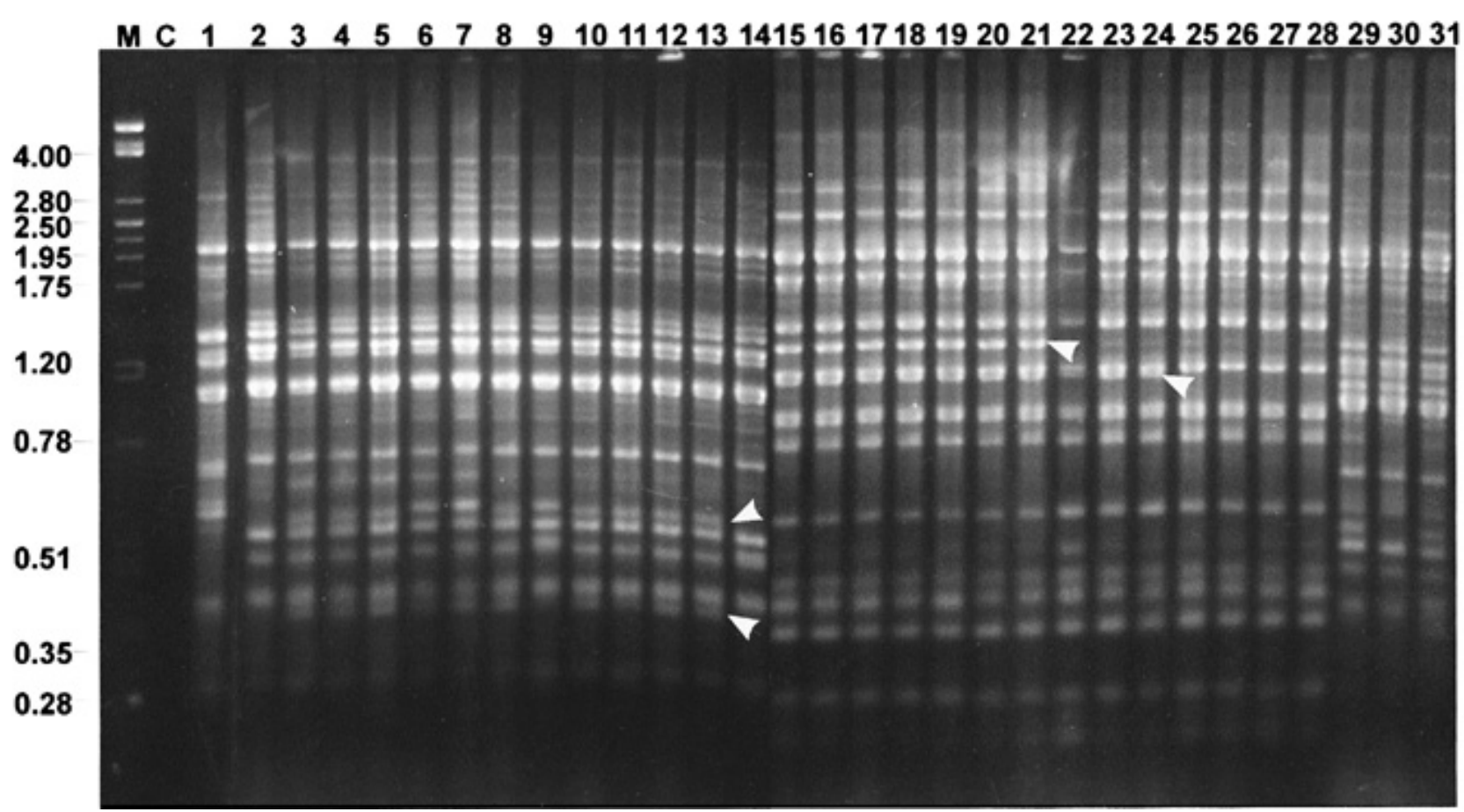

Fig. 2. Repetitive sequence-based polymerase chain reaction (rep-PCR) fingerprints obtained from representative strains of $P$. syringae pv. maculicola and pv. tomato with the BOX1AR primer. A portion of the PCR products $(8 \mu \mathrm{l})$ was loaded to a $1.5 \%$ agarose gel, and electrophoresis was performed at $70 \mathrm{~V}$ for $5 \mathrm{~h}$ in $1 \times$ TBE buffer. M, DNA molecular size marker ( $\lambda$ DNA PstI digestion); C, water control; sizes are indicated in kilobase pairs. Lanes 1 to 14 are Group A of $P$. syringae pv. maculicola. Lane 1, 4981; 2, 84-67; 3, 84-59; 4, 88-10; 5, 90-32; 6, DC3000; 7, OH314; 8, F10a; 9, F17; 10, F18; 11, F19; 12, F6; 13, F9; and 14, F1. Polymorphisms within group A are indicated within the region marked by arrowheads in lanes 13 (lanes 2 and 14 are A1, lanes 3 to 13 are A2, and lane 1 is A3). Lanes 15 to 28 are group B of $P$. syringae pv. maculicola. Lanes: 15, NF2; 16, NF3; 17, NF4; 18, NF5; 19, NF12; 20, 16392; 21,$16391 ; 22, \mathrm{~F} 20 ; 23, \mathrm{~F} 21 ; 24, \mathrm{~F} 22 ; 25,4326 ; 26,1820 ; 27,17223 ; 28,17225$. Polymorphisms in group B are indicated by arrowheads marking specific bands in lanes 21 and 24 (lanes 15 to 21 are B1, lanes 22 to 24 are B2, and lanes 25 to 28 are B3). Lanes 29 to 31 are P. syringae pv. tomato (group C). Lanes 29, 3357; 30, DC84-1; 31, 487. 
Genomic fingerprints generated by repPCR have been used to differentiate strains of $X$. campestris pv. vesicatoria (21) and $P$. syringae pvs. pisi and syringae (12). It has been proposed that $P$. syringae pvs. maculicola and tomato be combined based on similarities in nutrient utilization, DNA homology, and coronatine production $(5,8,28)$. In this study, the GN database for carbon source oxidation did not differentiate these two pathovars. Except for two strains of $P$. syringae pv. tomato (DC3000 and $\mathrm{OH} 314$ ), which were phenotypically similar to $P$. syringae pv. maculicola, our results showed that rep-PCR was useful for differentiating the two pathovars. In addition, polymorphisms within $P$. syringae pv. maculicola were identified. Several studies have shown that strains of $P$. syringae pv. maculicola are genetically more heterogeneous than strains of $P$. syringae pv. tomato $(8,18,30)$. Our results support the hypothesis that genetic variation is greater in pathovars with wide host ranges (20).

There were no obvious relationships between genomic fingerprint groups and phenotypic characteristics such as Biolog group, utilization of homoserine and sorbitol, lesion type, and host range. However, except for field 5 which contained repPCR groups A1 and B1, and field 7 which contained groups $\mathrm{A} 2$ and $\mathrm{A} 3$, most strains recovered within a field were in the same rep-PCR group, suggesting that strains within most fields originated from a single inoculum source.

The relative importance of $P$. syringae pv. maculicola in relation to pathovars of $X$. campestris involved in the leaf spot disease complex is not certain. Except for the stem and petiole lesions caused by $X$. $c$. pv. armoraciae (31), which the other pathogens do not cause, symptoms of the different bacteria can be difficult to differentiate in the field. In addition, selective media for the tentative identification of $P$. syringae are not available. Genetic fingerprints using rep-PCR should be beneficial for rapid identification of purified isolates.

More recently, $P$. syringae pv. maculicola has continued to be a major pathogen in fields of leafy crucifers in Oklahoma. Severe epidemics have been observed in the spring and fall production seasons of 1998 and in the spring of 1999. In general disease problems are most severe in the spring production season when rainfall is more abundant. Although most fields are watered with overhead sprinklers, irrigation alone does not trigger epidemics because little disease develops in dry production seasons. Attempts by growers to control the disease with copper sprays have not been successful.

\section{ACKNOWLEDGMENTS}

We thank D. Cuppels, and R. Stall for providing strains of bacteria, and Jacqueline Fletcher, Bob Hunger, and Lisa Keith for reviewing the manuscript. Approved for publication by the Director, Oklahoma Agricultural Experiment Station.
This research was funded in part by the Oklahoma Agricultural Experiment Station and National Science Foundation grant MCB-9603618.

\section{LITERATURE CITED}

1. Alippi, A. M., and Ronco, L. 1996. First report of crucifer bacterial leaf spot caused by Pseudomonas syringae pv. maculicola in $\mathrm{Ar}-$ gentina. (Abstr.) Plant Dis. 80:223.

2. Anonymous. 1994. The importance of plant disease management in US. Production of leafy green vegetables. USDA- the National Agric. Pesticide Impact Assessment Program, Report no. 1-CA-94.

3. Bender, C. L. 1999. Chlorosis-inducing phytotoxins produced by Pseudomonas syringae. Eur. J. Plant Path. 105:1-12.

4. Bender, C. L., Malvick, D. K., and Mitchell, R. E. 1989. Plasmid-mediated production of the phytotoxin coronatine in Pseudomonas syringae pv. tomato. J. Bacteriol. 171:807-812.

5. Bereswill, S., Bugert, P., Voelksch, B., Ullrich, M., Bender, C. L., and Geider, K. 1994. Identification and relatedness of coronatineproducing Pseudomonas syringae pathovars by PCR analysis and sequence determination of the amplification products. Appl. Environ. Microbiol. 60:2924-2930.

6. Bradbury, J. F. 1986. Guide to Plant Pathogenic Bacteria. CAB, Slough, England.

7. Campbell, R. N., Greathead, A. S., and Sim, S. T. 1987. Pepper spot of crucifers in California. Pages 668-671 in: Proc. 6th Int. Conf. Plant Pathog. Bacteria. C. L. Civerolo, A. Collmer, R. E. Davis, and A. G. Gillaspie, eds. Martinus Nijhoff, Dordretht, Netherlands.

8. Clerc, A., Manceau, C., and Nesme, X. 1998. Comparison of randomly amplified polymorphic DNA with amplified fragment length polymorphism to assess genetic diversity and genetic relatedness within genospecies III of Pseudomonas syringae. Appl. Environ. Microbiol. 64:1180-1187.

9. Cuppels, D. A., and Ainsworth, T. 1995. Molecular and physiological characterization of Pseudomonas syringae pv. maculicola strains that produce the phytotoxin coronatine. Appl. Environ. Microbiol. 61:35303536.

10. Gitaitis, R. D., Sasser, M. J., Beaver, R. W., McInnes, T. B., and Stall, R. E. 1987. Pectolytic xanthomonads in mixed infection with Pseudomonas syringae pv. syringae, Pseudomonas syringae pv. tomato, and Xanthomonas campestris pv. vesicatoria in tomato and pepper transplants. Phytopathology 77:611-615.

11. Hendson, M., Hildebrand, D. C., and Schroth, M. N. 1992. Relatedness of Pseudomonas syringae pv. tomato, Pseudomonas syringae pv. maculicola and Pseudomonas syringae pv. antirrhinii. J. Appl. Bacteriol. 73:455-464.

12. Hollaway, G. J., Gillings, M. R., and Fahy, P. C. 1997. Use of fatty acid profiles and repetitive element polymerase chain reaction (PCR) to assess the genetic diversity of Pseudomonas syringae pv. pisi and Pseudomonas syringae pv. syringae isolated from field peas in Australia. Aust. Plant Path. 26:98-108.

13. Jones, J. B., Chase, A. R., and Harris, G. K. 1993. Evaluation of the Biolog GN microplate system for identification of some plant-pathogenic bacteria. Plant Dis. 77:553-558

14. Keane, P. J., Kerr, A., and New, P. B. 1970. Crown gall of stone fruit. II. Identification and nomenclature of Agrobacterium isolates. Aust. J. Biol. Sci. 23:585-595.

15. King, E. O., Ward, M. K., and Raney, D. E. 1954. Two simple media for the identification of pyocyanin and fluorescein. J. Lab. Clin. Med. 44:301-307.

16. Koike, S. T., Henderson, D. M., Azad, H. R., Cooksey, D. A., and Little, E. L. 1998. Bacterial blight of broccoli raab: A new disease caused by a pathovar of Pseudomonas syringae. Plant Dis. 82:727-731

17. Lelliott, R. A., Billing, E., and Hayward, A. C. 1966. A determinative scheme for the fluorescent plant pathogenic pseudomonads. J. Appl. Bacteriol. 29:470-489.

18. Little, E. L., and Gilbertson, R. L. 1997. Phenotypic and genetic characters support placement of Pseudomonas syringae strains from tomato, celery, and cauliflower into distinct pathovars. Pages 542-547 in: Pseudomonas syringae Pathovars and Related Pathogens. K. Rudolph, T. J. Burr, J. W. Mansfield, D. Stead, A. Vivian, and J. von Kietzell, eds. Kluwer Academic Publishers, Dordrecht, The Netherlands.

19. Louws, F. J., Bell, J., Medina-Mora, C. M. Smart, C. D., Opgenorth, D., Ishimaru, C. A. Hausbeck, M. K., de Bruijn, F. J., and Fulbright, D. W. 1998. Rep-PCR-mediated genomic fingerprinting: A rapid and effective method to identify Clavibacter michiganensis. Phytopathology 88:862-868.

20. Louws, F. J., Fulbright, D. W., Stephens, C. T., and de Bruijn, F. J. 1994. Specific genomic fingerprints of phytopathogenic Xanthomonas and Pseudomonas pathovars and strains generated with repetitive sequences and PCR. Appl. Environ. Microbiol. 60:2286-2295.

21. Louws, F. J., Fulbright, D. W., Stephens, C. T., and de Bruijn, F. J. 1995. Differentiation of genomic structure by rep-PCR fingerprinting to rapidly classify Xanthomonas campestris pv. vesicatoria. Phytopathology 85:528 536.

22. McCulloch, L. 1911. A spot disease of cauliflower. USDA Bur. Plant Ind. Bull. 225:1-15.

23. Palmer, D. A., and Bender, C. L. 1993. Effects of environmental and nutritional factors on production of the polyketide phytotoxin coronatine by Pseudomonas syringae pv. glycinea. Appl. Environ. Microbiol. 59:1619-1626.

24. Rohlf, F. J. 1992. NTSYS-PC: Numerical taxonomy and multivariate analysis system. Version 1.70, Exeter Software, Setauket, New York.

25. Sambrook, J., Fritsch, E. F., and Maniatis, T. 1989. Molecular Cloning: A Laboratory Manual. 2nd Ed. Cold Spring Harbor Laboratory Press, Cold Spring Harbor, New York.

26. Schaad, N. W., ed. 1988. Laboratory Guide for Identification of Plant Pathogenic Bacteria. 2nd Ed. American Phytopathological Society, St. Paul, MN

27. Sherf, A. F., and MacNab, A. A. 1986. Vegetable Diseases and Their Control. 2nd Ed. John Wiley and Sons, New York.

28. Takikawa, Y., Nishiyama, N., Ohba, K., Tsuyuma, S., and Goto, M. 1992. Synonymy of Pseudomonas syringae pv. maculicola and Pseudomonas syringae pv. tomato. Pages 199-204 in: Proc. 8th. Int. Conf. Plant Pathog. Bact. M. Lemattre, S. Freigoun, K. Rudolph, and J. G. Swings, eds. INRA, Paris.

29. Versalovic, J., Schneider, M., de Bruijn, F. J., and Lupski, J. R. 1994. Genomic fingerprinting of bacteria using repetitive sequencebased polymerase chain reaction. Meth. Mol Cell. Biol. 5:25-40.

30. Wiebe, W. L., and Campbell, R. N. 1993. Characterization of Pseudomonas syringae pv. maculicola and comparison with P. s. tomato. Plant Dis. 77:414-419.

31. Zhao, Y., Damicone, J. P., Demezas, D. H., and Bender, C. L. 2000. Bacterial leaf spot diseases of leafy crucifers in Oklahoma caused by pathovars of Xanthomonas campestris. Plant Dis. 84:1008-1014.

32. Zhao, Y., Damicone, J. P., Demezas, D. H., Rangaswamy, V., and Bender, C. L. 1998. Characterization of bacterial leaf spots of leafy green vegetables in Oklahoma. (Abstr.) Phytopathology 88:S104. 